$$
\text { "tmcs-kantor" — 2010/4/12 — 23:44 — page } 109 \text { — \#1 }
$$

\title{
Hungarian mathematicians in the twentieth century Ottó Varga (1909-1969)
}

\author{
TÜNDE KÁNTOR
}

Abstract. In this article we want to present life and work of Ottó Varga on occasion of the centenary of his birth. He was an outstanding geometer, the head of the Mathematical Seminar / Department (1942-1959) and the first dean of the Faculty of Sciences of the University of Debrecen (Hungary).

His area of research was differential geometry. The Debrecen school of differential geometry emerged due his activity. He wrote 57 papers.

Key words and phrases: differential geometry, L. Berwald, W. Blaschke, Hamburg school of differential geometry, University of Debrecen, Publicationes Mathematicae, the Debrecen school of differential geometry.

ZDM Subject Classification: A30, G90, I60.

Ottó Varga (born in Szepetnek, 22nd November 1909; died in Budapest, 14th June 1969), professor, head of department, member of the Hungarian Academy of Sciences.

His father Imre Varga was a Lutheran minister. His mother Margit Henning was of German origin. He had an elther brother, who died young. The family moved from Szepetnek in 1910, first to Zagreb (Hungarian Zágráb) for a short period, then to Poprad (Hungarian Poprád), where Imre Varga worked as a Lutheran minister, and later he became the archdeacon of the Szepes region.

Ottó Varga attended a Hungarian primary school, but his teacher was German. He was a private student, later a day student in the German Lutheran secondary school of Kežmarok (Hungarian Késmárk) between 1919 and 1927. He

Copyright (C) 2010 by University of Debrecen 


$$
\text { "tmcs-kantor" — 2010/4/12 — 23:44 — page } 110 \text { — \#2 }
$$

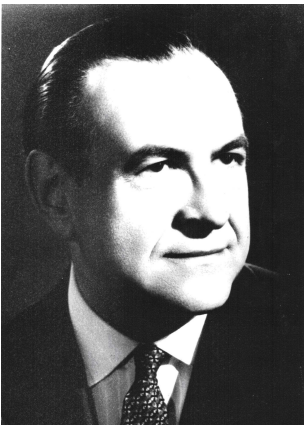

Figure 1. Ottó Varga

and his brother took their final exams here. These were the formative years for his academic career. His first stirring experiences were the classes of Károly Bruckner, director and teacher of mathematics of the Lutheran secondary school of Kežmarok. He loved descriptive geometry as well. For a long time he did not understand why the teacher explained so much, why he kept repeating and illustrating details, whereas he found everything clear from the first moment, and he saw lines and planes in space exactly. Later he also made a good use of his extraordinary stereoscopic vision in his world-famous studies in differential geometry. He also emphasized in his university lectures that he first imagined everything in three-dimensional space before generalizing ideas to $n$ dimensions.

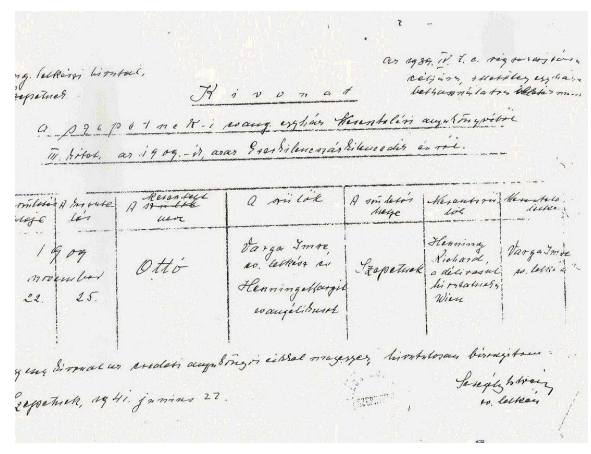

(a) Birth certificate

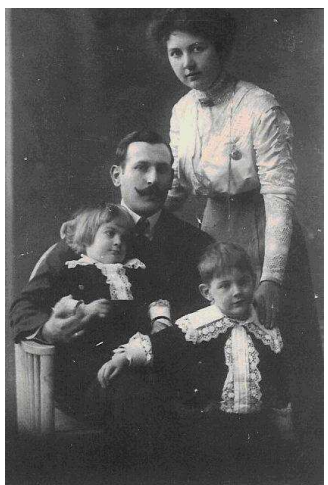

(b) With his parents and elder brother (1911)

Figure 2
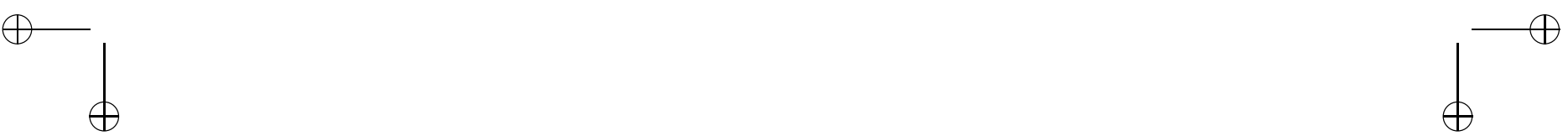


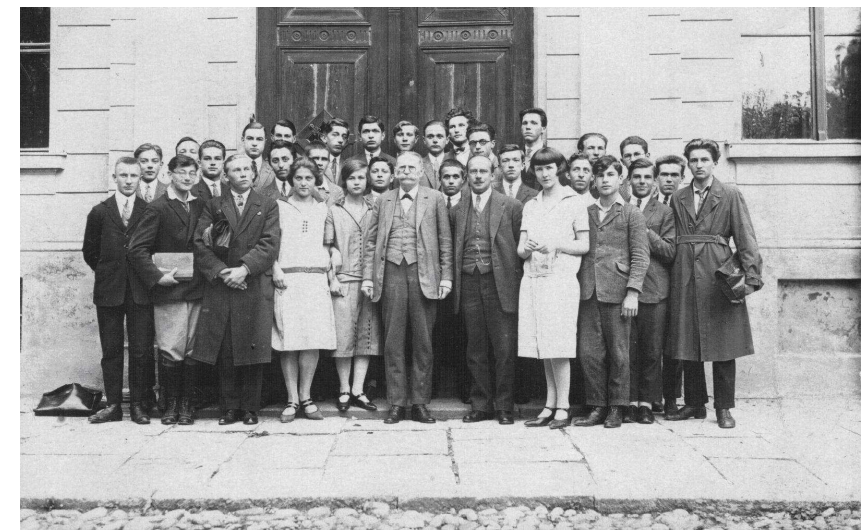

Figure 3. As a student before the German Lutheran School of Késmárk with the director and mathematics teacher Károly Bruckner and with his elder brother (1927)

He was considered a good mathematician at secondary school, thus he was charged with teaching fellow-students of small ability. He was 16 when he met the third Vienna edition from 1859 of the book Compendium of Higher Mathematics by Adam Ritter von Burg. It was then that he realized how little he knew about mathematics. Later he cherished it as an heirloom with his original pencil notes.

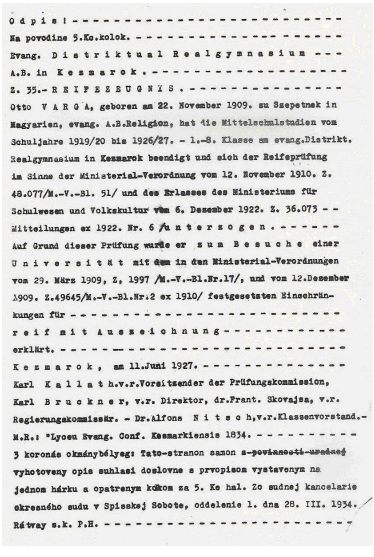

(a) Certificate of final exam (Késmárk, 11.06.1927)

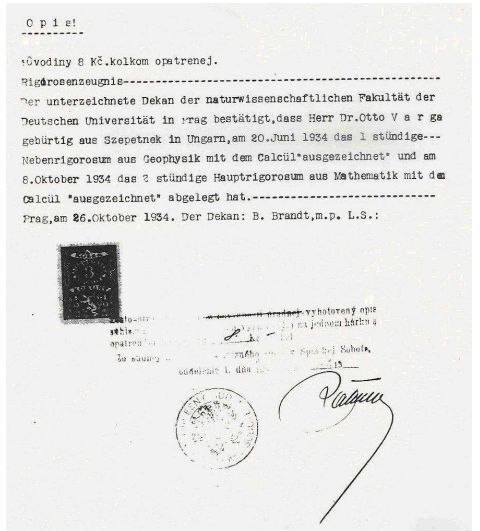

(b) $\mathrm{PhD}$ certificate (Prague, 26.10. 1934)

Figure 4
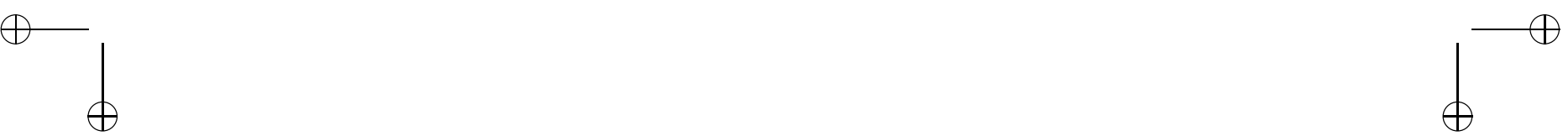


$$
\text { "tmcs-kantor" — 2010/4/12 — 23:44 — page } 112 \text { — \#4 }
$$

In 1927, at his father's request, he chose a practical profession, and he started his studies at the Faculty of Architecture of the Technical University of Vienna. He was interested here mainly in subjects of mathematics and descriptive geometry, but he found insufficient the mathematics taught to students of architecture.

He continued his studies in Prague from 1928, where he became an ordinary student of the Faculty of Sciences of the University and an extraordinary student of the Technical University. At that time, L. Berwald, the famous professor of differential geometry taught at the German University of Prague. Recognizing Varga's talent, Berwald directed his interest towards differential geometry. He graduated in 1933 as a teacher of mathematics and descriptive geometry.

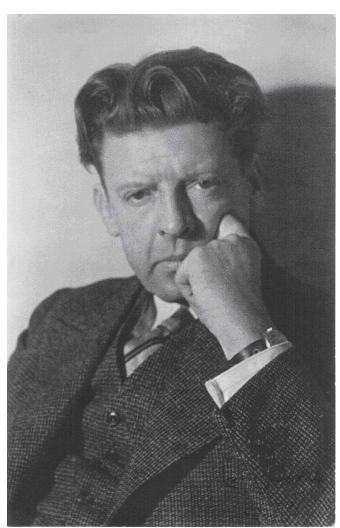

(a) W. Blaschke (Hamburg)

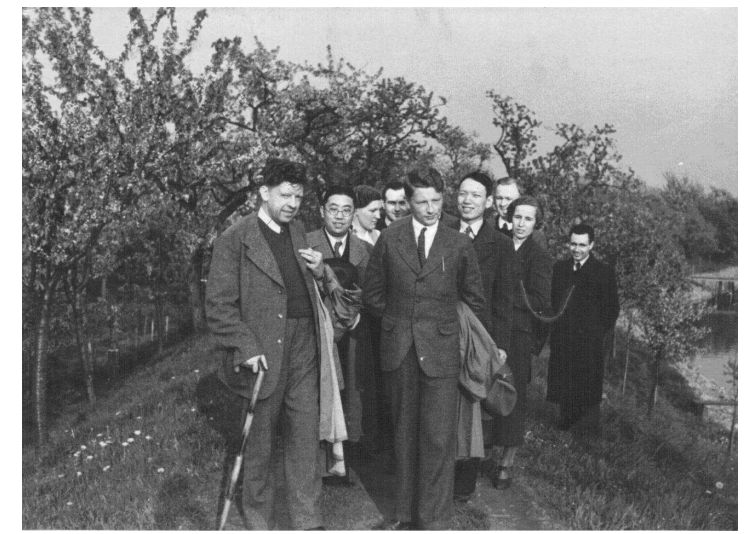

(b) The famous Hamburg school of geometry (1936) W. Blaschke, A. Kawaguchi, L. Santaló, O. Varga, S. S. Chern, B. Petkancsin

Figure 5

He obtained his Ph.D. degree in 1934 under the supervision of L. Berwald, then, following his advice, he continued his studies in professor W. Blaschke's institute, in the famous Hamburg school of geometry, in the academic year 193435. Here he made investigations in differential and integral geometry. At that time W. Blaschke led an excellent school (S. S. Chern and A. Kawaguchi worked here among others), and Varga achieved outstanding results in integral geometry, which he applied later to Finsler geometry and geometrical optics. In 1936 he got a job in the Institute of Mathematics of the University of Prague, where he became an assistant of L. Berwald. He acquired his Habilitation in 1937. His 


$$
\text { "tmcs-kantor" — 2010/4/12 — 23:44 — page } 113 \text { - \#5 }
$$

thesis still serves as a standard in geometric characterization of various kinds of spaces. He applied the method of so-called osculating spaces.

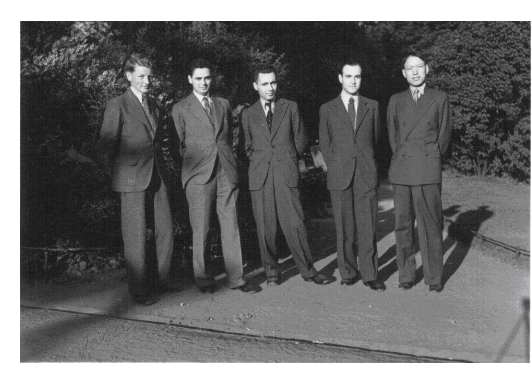

(a) The famous Hamburg school of geometry (1936) L. Santaló, B. Petkancsin, X.Y., O. Varga, S.S.Chern

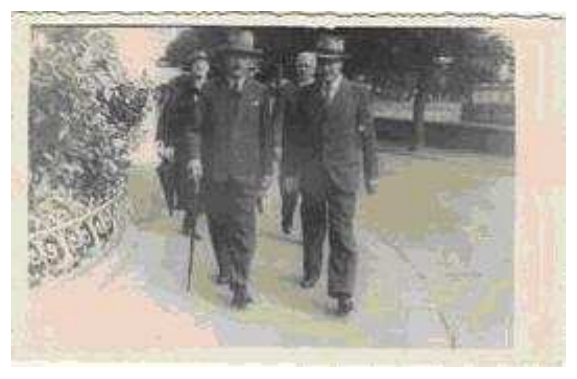

(b) Ottó Varga in Karlsbad perhaps with Ludwig Berwald

\section{Figure 6}

The German occupation of Prague caused him political inconvenience, which was mainly owing to his close professional relationship to professor L. Berwald. Later Berwald was carried off to a ghetto by the Germans, where he died.

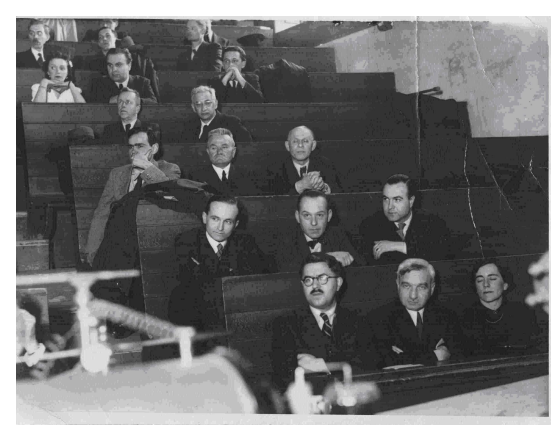

(a) Giving out of the König Prizes (1944) 2. row: Gy. Hajós, X.Y., O. Varga

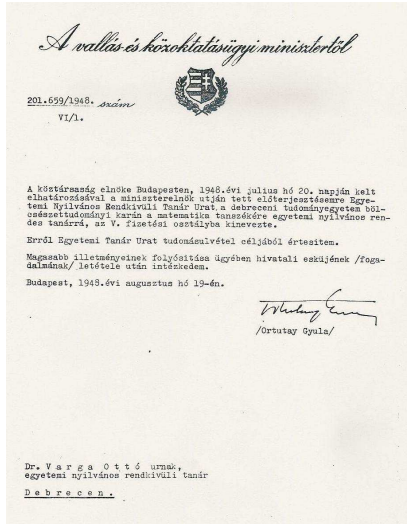

(b) Letter of appointment (1948)

\section{Figure 7}

In 1941 Varga returned to Hungary. He was invited to Cluj (Hungarian Kolozsvár) by Béla Szőkefalvi-Nagy and to Debrecen by Sándor Szalay to teach 


$$
\text { "tmcs-kantor" — 2010/4/12 - 23:44 — page } 114 \text { - \#6 }
$$

at the university. Varga accepted first the invitation by the University of Cluj, there he became professor and he obtained his Habilitation again. He went to the University of Debrecen in 1942. His task was the strengthening and improving of the Mathematical Seminar. He did this task excellently.

The Debrecen school of differential geometry emerged due to his activity, and the other branches of mathematics also started to prosper.

In 1944 Varga was awarded the Gyula König Medal by the Mathematical and Physical Society.

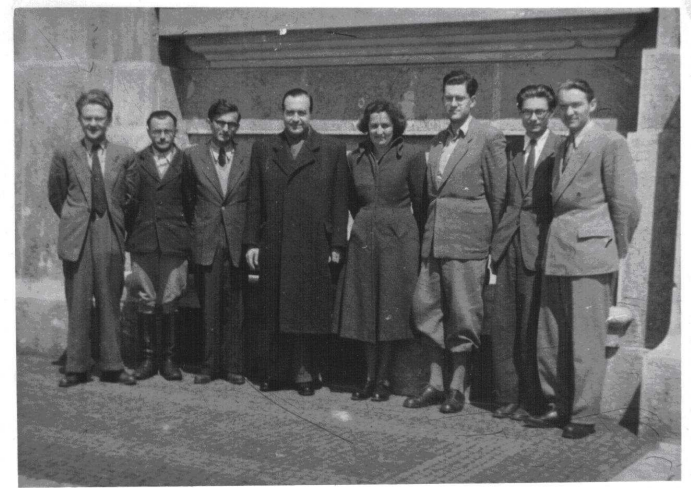

Figure 8. O. Varga with his students in Debrecen (1948/49)

A. Ménes, Gy. K. Tóth, Gy. Soós, O. Varga, I. Nagy, D. Berényi, K. Nagy, I. Berecz

In 1947 he was elected as extraordinary, then in 1948 as ordinary professor of the university of Debrecen. In 1949 together with Alfréd Rényi and Tibor Szele he founded Publicationes Mathematicae, the mathematical journal of Debrecen, which became later internationally renowned.

After the establishment of the Faculty of Sciences he became the head of the Institute of Mathematics. He organized the teaching of mathematics and descriptive geometry following the standard of the University of Vienna.

During the years in Debrecen he published several excellent papers on differential geometry.

His areas of research were differential geometry and integral geometry, in particular the geometry of Finsler and Minkowski spaces.

As early as in his Ph.D. thesis he gave a setting of Finsler geometry equivalent to Cartan's. He defined affinely connected line element spaces, he described the 


$$
\text { "tmcs-kantor" — 2010/4/12 - 23:44 — page } 115-\# 7
$$

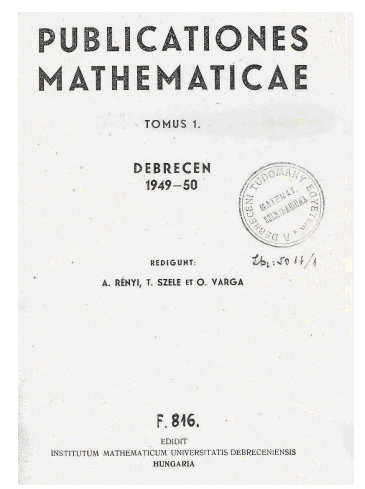

(a) Publicationes Mathematicae Tomus 1. Debrecen $1949-50$

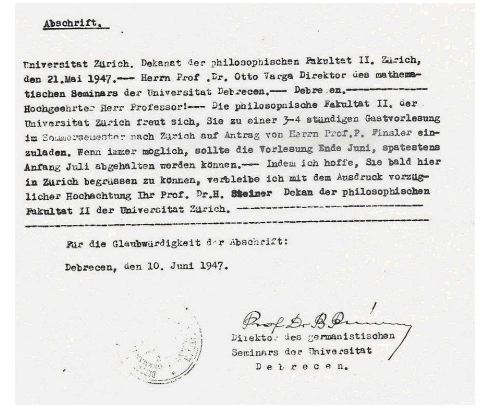

(b) Invitation to the University of Zurich (1947)

\section{Figure 9}

differential equations of parallel translations along a curve, and he investigated the invariant differentials in Finsler spaces. He gave a characterization of Finsler spaces having an absolute parallelism of the line elements. He also examined curvature tensors.

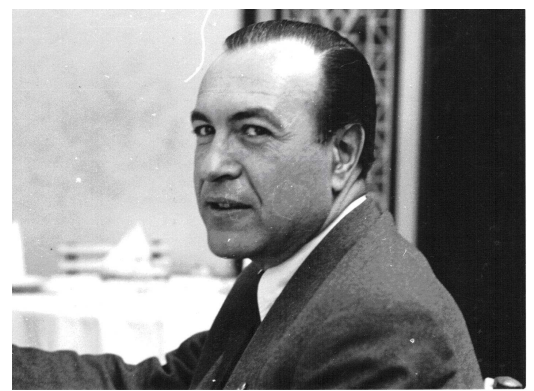

(a) In Tóth's café (Debrecen)

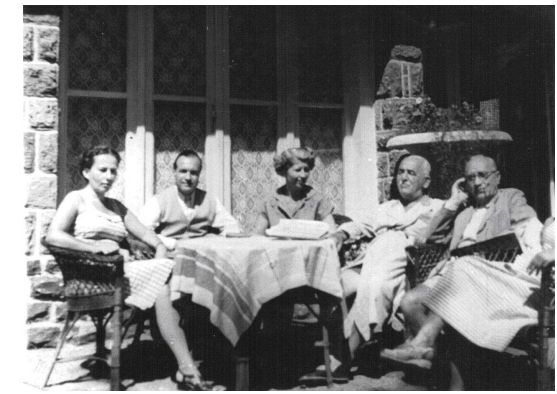

(b) On Holiday (Mátraháza) Mrs. ErdeyGrúz, O. Varga. Mrs. Szabó, F. Riesz, Gy. Németh (Turkic researcher)

Figure 10

His papers on the foundations of Minkowski geometry, the characterization of surfaces of scalar and constant curvature in Finsler geometry and the geometric meaning of Cartan's tensor $S$ are especially important. 
His scientific results were renowned worldwide. He gave many lectures at universities and conferences abroad (Prague, Zürich, Sofia, Bratislava, Vienna, Graz, Dresden, Oberwolfach, Berlin, Edinburgh). He had no language problems, since he spoke German and Czech as proficiently as a native speaker.

In his talk on the 1st Hungarian Mathematical Congress in 1950 he determined the complete system of invariants of general affinely connected space with the help of the geometric interpretation of normal coordinates. He also dealt with Hilbert's foundation of geometry, with its construction and characterization.

Owing to his outstanding scientific work he was elected a corresponding member of the Hungarian Academy of Sciences in 1950 and an ordinary member in 1965. In 1952 he was awarded with Kossuth Prize.

It was in Debrecen in 1945 that he met his future wife Jolán Pukánszky. She was the sister of the well-known mathematician Lajos Pukánszky.

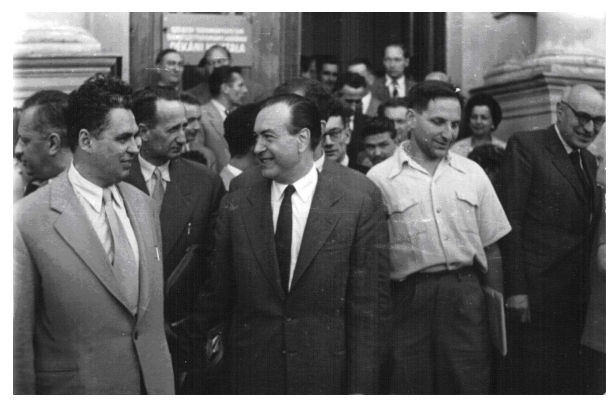

(a) 10. Anniversary of the Hungarian Mathematical Society (Szeged, 1957) B.Petkancsin, O. Varga, P. Szüsz, A. Rapcsák, L. Tamássy

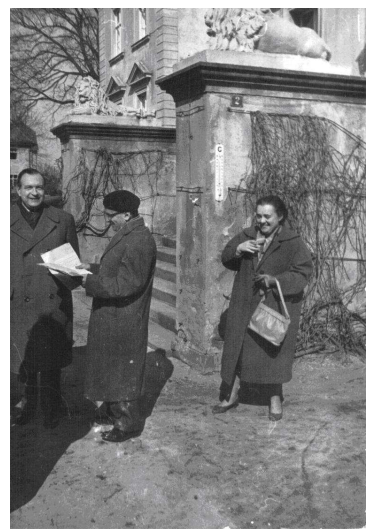

(b) Mathematical Congress in Dresden (1957) Before the Zwinger O. Varga, J. Aczél, Zs. Aczél

Figure 11

Lajos Pukánszky lived from 1957 in U.S.A. His areas of interest were operator algebras, in particular von Neumann algebras and quasi-unitary algebras, representations of Lie groups, in particular exponential and solvable Lie groups. (See (4)).

She also worked in the Institute of Mathematics with Béla Gyires. They got married in 1947 and had one daughter, Borbála. 


$$
\text { "tmcs-kantor" — 2010/4/12 — 23:44 — page } 117 \text { — \#9 }
$$

Varga liked Debrecen and the patriarchal country atmosphere, but in his heart he craved for the life in a big city, and he wanted to move to Budapest. In 1946 he did not manage to get a job at Loránd Eötvös University in Budapest. In 1954, after the death of Gyula Szőkefalvi-Nagy he was invited to Szeged, but he did not go there. Later, in 1959, professor Jenő Egerváry invited him to be a professor at the Department of Mathematics of the Faculty of Architecture of the Technical University of Architecture and Transport in Budapest.

In 1967 he was promoted to a senior member of the Institute of Mathematical Research of the Hungarian Academy of Sciences. Here he had already led the research group in differential geometry since 1958.

He published 57 papers in various renowned journals. As a scientist he was outstandingly profound, conscientious and inventive. His geometric intuition and his ability to shed light on problems made a deep impression on his students. It was he who started off László Gyarmathi, András Rapcsák, József Merza, Arthur Moór, Gyula Soós and Lajos Tamássy on their scientific career.

His method to attack a problem was to start from the corresponding problem of ordinary three-dimensional space, and it was there that he tried visualizing connections in more complicated spaces to himself and to others.

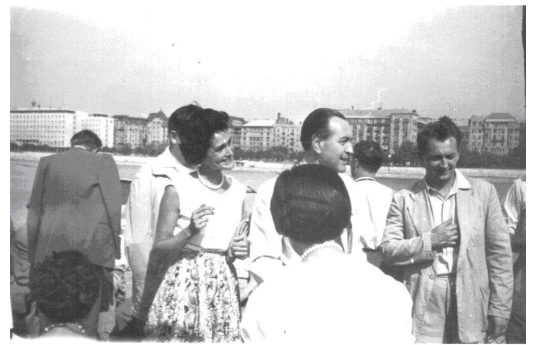

(a) Boat-excursion II. Hungarian Mathematical Congress (Budapest, 24.08. 1960) Mrs. Varga, Prof. O. Varga

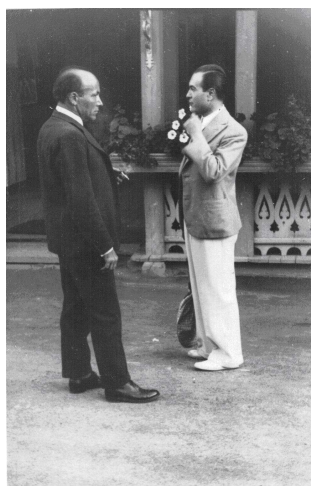

(b) J. Egerváry and $\mathrm{O}$. Varga (Tatranske Polianka)

Figure 12

He was not a scientist of quick, sparkling wits. He kept saying that he would hardly do very well in a competition for students. But what he conceived and thought over carefully in his silent loneliness always contributed substantially to 


$$
\text { "tmcs-kantor" — 2010/4/12 — 23:44 — page } 118 \text { — \#10 }
$$

the development of differential geometry and it was always free from flaws and errors.

He planned to write a three-volume monograph of differential geometry together with András Rapcsák and Gyula Soós, but this plan remained unfulfilled.

He always complained much about his health. He had his first cardiac infarction in 1961. In 1962 he had a more serious one, which resulted in a myocardial degeneration. Afterwards he became tired very easily. His doctor prohibited him even from climbing mountains.

He was very sociable, and he always dressed elegantly.

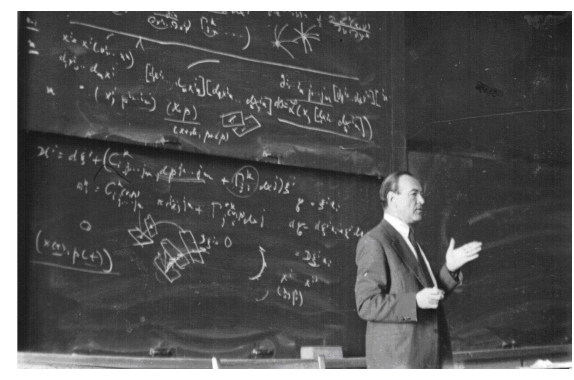

(a) Lecturing at the University

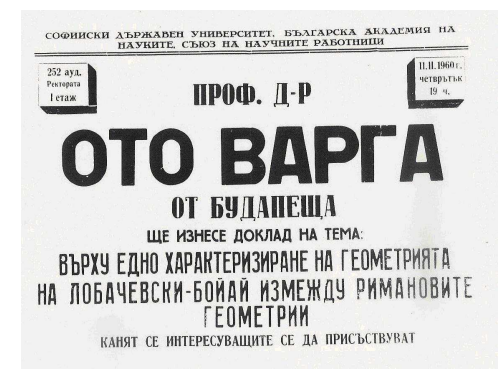

(b) Lecture at the University of Sofia (1960)

Figure 13

His university lectures were of high standard, and he aimed at realizing the mentality of the best universities abroad. During the period when he taught at the technical university he tried to improve the mathematical education of students of engineering, and he contributed to the programme and thematics of reformed education.

During his Debrecen period József Merza made extensive notes on his lectures, which formed the basis of the lecture notes Fundamentals of Geometry and Projective Geometry, which have become cherished heirlooms by now.

He did not like examining students, and he asked them only questions which helped them. He was always very patient. He loved instructing talented young people.

He corresponded extensively with celebrated scientists from abroad (P. Finsler, H. Hadwiger, L. Santaló, D. Laugwitz, W. Rinow, A. Lichnerowicz, Ch. Ehresmann, R. Sulanke, G. Vranceanu, B. Petkancsin). 


$$
\text { "tmcs-kantor" — 2010/4/12 — 23:44 — page } 119 \text { — \#11 }
$$

He was an enthusiastic linguist, and he wanted to discuss the problems of Slavonic languages from a mathematical viewpoint.

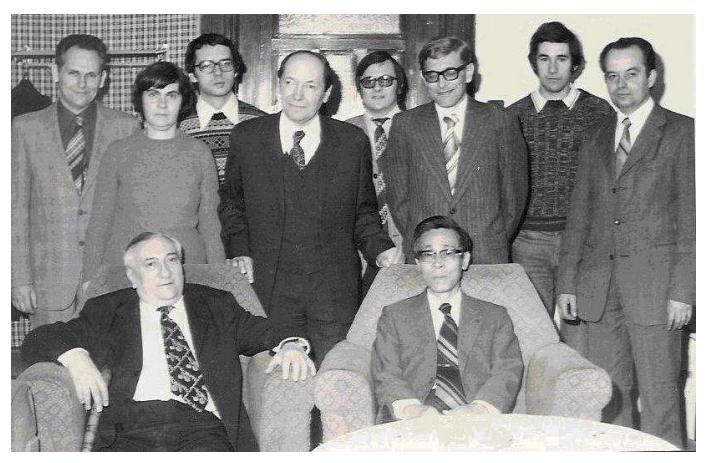

Figure 14. Differential geometrical school of Debrecen A. Rapcsák, M. Matsumoto, A. Gyarmati, T. Kántor, J. Szilassy, L. Tamássy, S. Bácsó, K. Bélteky, J. Varga, J. Szabó

His hobby was reading novels whose plots take place in Upper Hungary. In Debrecen he used to play tennis with Béla Barna, László Gyarmathi and Lajos Tamássy, and he sometimes went to Tóth (Pálma) Café in Simonyi street with Béla Gyires and András Rapcsák to have a chat. In Budapest he used to walk with László Fejes Tóth to Hármashatárhegy, or he went to Lukács Café in Andrássy street with Gyula Strommer.

In Hungary Ottó Varga was the leading scientist in differential geometry and he became the founder of the Debrecen School of Differential Geometry.

Most important selected papers of Ottó Varga

(1) Beiträge zur Theorie der Finslerschen Räume und der affinzusammenhängenden Räume von Linienelementen (Contributions to the theory of Finsler spaces and affinely connected line element spaces). Lotos, Prague 84 (1936), $1-4$.

(2) Integralgeometrie 9. Mittelwerte an Eikörpern. Mathematica 12, 65-80 (with W. Blaschke).

(3) Zur Herleitung des invarianten Differentials in Finslerschen Räumen (On the deduction of the invariant differentials in Finsler spaces). Monatshefte Math. und Phys. 50 (1941), 165-175.

(4) Normalkoordinaten im allgemeinen Räumen und ihre Verwendung zur Bestimmung sämtlicher Differentialinvarianten (Normal coordinates in general 


$$
\text { "tmcs-kantor" — 2010/4/12 — 23:44 — page } 120 \text { — \#12 }
$$

affinely connected space) Comptes Rendus de I. Congres des Math. Hongrois (1950), 147-162.

(5) Az integrálgeometria alkalmazásai a geometriai optikában (Hungarian: Applications of integral geometry in geometrical optics). MTA III. Oszt. Közleményei 1 (1951), 192-201.

(6) Eine geometrische Charakterisierung der Finslerschen Räume skalarer und konstanter Krümmung (A geometric characterization of Finsler spaces of scalar and constant curvature). Acta Math. Acad. Sci. Hung. 2 (1951), 281283.

(7) Zur Begründung der Hilbertschen Verallgemeinerung der nichteuklidischen Geometrie (About foundation of Hilbert's generalization of noneuclidean geometry). Monatshefte für Math.66 (1962), 265-275.

(8) Über Hyperflächen konstanter Normalkrümmung in Minkowskischen Räumen (On hypersurfaces of constant normal curvature in Minkowski spaces). Tensor N. S. 13 (1963), 246-250.

(9) Beziehung der ebenen verallgemeinerten nichteuklidischen Geometrie zu gewissen Flächen im pseudominkowskischen Raum (The connection between generalized non-Euclidean plane geometry and certain surfaces in a pseudoMinkowski space). Aequationes Math. 3 (1969), 112-117.

\section{References}

[1] T. Kántor, Varga Ottó, Pedagógusok Arcképcsarnoka, Debrecen, 2002, 193-195.

[2] M. Lerch, Varga Ottó élete és munkássága, szakdolgozat, Debrecen, 1972.

[3] L. Tamássy, Ottó Varga In memoriam 1909-1969, Publicationes Math. 17 (1970), 19-26.

[4] T. Kántor-Varga, Biographies, A Panorama of Hungarian Mathematics in the Twentieth Century, (J. Horváth, ed.), Springer, 2006, 565-607.

TÜNDE KÁNTOR

UNIVERSITY OF DEBRECEN

DEPARTMENT OF GEOMETRY

DEBRECEN

HUNGARY

E-mail: tkantor@math.klte.hu

(Received June, 2009)
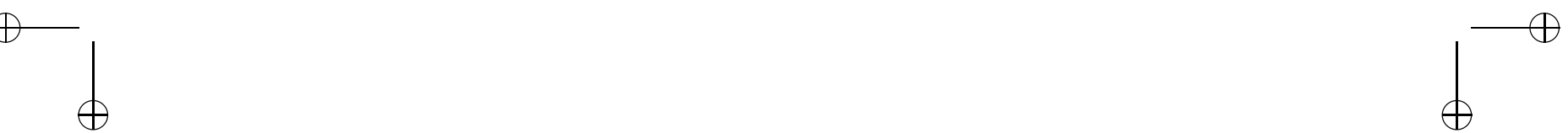